\title{
Inevitability of an Enhanced Monitoring Strategy to Reduce Water Borne Illness Combining Indicators of Sanitary Protection and Measuring Water Quality
}

\author{
Nain Taara Bukhari'1, Ghulam Fatima², Urooj Zafar ${ }^{3}$, Anum Muneer ${ }^{1}$, Shahana Urooj Kazmi1 \\ ${ }^{1}$ Dadabhoye Institute of Higher Education, Karachi, Pakistan \\ ${ }^{2}$ Civil Hospital, Karachi, Pakistan \\ ${ }^{3}$ Immunology and Infectious Diseases Research Laboratory, Karachi, Pakistan \\ Email: nain.bukhari@yahoo.com
}

How to cite this paper: Bukhari, N.T., Fatima, G., Zafar, U., Muneer, A. and Kazmi, S.U. (2016) Inevitability of an Enhanced Monitoring Strategy to Reduce Water Borne Illness Combining Indicators of Sanitary Protection and Measuring Water Quality. International Journal of Clinical Medicine, 7, 748-755

http://dx.doi.org/10.4236/ijcm.2016.711081

Received: September 29, 2016 Accepted: November 25, 2016

Published: November 28, 2016

Copyright $\odot 2016$ by authorS and Scientific Research Publishing Inc. This work is licensed under the Creative Commons Attribution International License (CC BY 4.0).

http://creativecommons.org/licenses/by/4.0/ (c) (i) Open Access

\begin{abstract}
Background: Diarrhoea is the second leading cause of childhood mortality in children under five years old. Water is a major contributing risk factor for this disease that is a common illness and a global killer. Material and Methods: Water samples from different areas of Karachi were collected and were processed by MPN technique to evaluate the presence of microbiological substances. Results: Out of the processed samples, $64 \%$ were positive for the presence of mix enteric pathogen from different areas of Karachi; from Bhens colony, $74 \%$ were positive for the presence of fecal coli forms, among which $4 \%$ were positive for EHEC isolated from storage tank and water tank. Conclusion: The abovementioned results reflect the presence of organisms of public health importance in different sources of drinking water. According to WHO guidelines, there should be zero tolerance of these organisms in water.
\end{abstract}

\section{Keywords}

Acute Watery Diarrhea, Parasites, Pathogens

\section{Introduction}

Worldwide 1.1 billion people lack access to improved water supplies and 2.4 billion do not have access to sanitation services while hundreds of millions rely on unimproved water supplies that are not safe because of microbial or chemical contamination [1]. 
Diarrheal diseases are infections caused by a group of bacterial, viral and parasitic organisms and the second leading cause of death in children under five years old, responsible for killing around 760,000 children every year [2] [3]. Children who are malnourished or immune compromised are at high risk of life-threatening diarrhea. The mode of transmission of such pathogens is food and water sources contaminated with human and animal feces. Most common source of entry is sewage, septic tanks and latrines [4] [5].

Approximately 25\% Karachi's total population of 16 million people lives below the poverty line. Overcrowding, poverty and low socio economic status, frequent episodes of illness, poor sanitation and hygienic practice, use of contaminated drinking water and food, limited access of populations to their basic needs and high number of reported diarrheal cases from these areas were the major reasons to conduct this study in those areas. Unfortunately, environmental factors, diseases, inadequate sanitation and lack of safe drinking water even make the living condition worse in above mentioned study areas. Due to all of the above mentioned factors, the increase number of reported cases from these areas was the major reason to conduct this study there to relate the relationship of drinking water with waterborne diseases [6] [7] [8].

Public and environmental health protection requires safe drinking water, which means that it must be free of pathogens. Among the pathogens disseminated in water sources, enteric pathogens are the ones that are most frequently encountered [6]. As a consequence, sources of fecal pollution in waters devoted to human activity must be strictly controlled. Enteric pathogens, such as Escherichia coli O157:H7, are generally present at very low concentrations in environmental water within a diversified micro flora [2]. Food is another major cause of diarrhea when it is prepared by water stored in unhygienic conditions. Water can contaminate food during irrigation. Fish and seafood from polluted water may also contribute to the disease.

In developing countries, children under five years old experience three episodes of diarrhea on average every year. Each episode deprives the child of the nutrition necessary for growth. Infection is more common when there is a shortage of adequate sanitation and hygiene and safe water for drinking, cooking and cleaning. Interventions to prevent diarrhea, including safe Diarrhea, can be treated with a solution of clean water provision [7].

In a local study conducted presence of trace metals (nickel, copper, chromium, lead, cobalt, manganese and iron) was confirmed in drinking water samples when the concentration of metals was compared with the World Health Organization (WHO) drinking water quality guideline values, reflecting the adverse health effects to the inhabitants of Karachi due to the oral ingestion and dermal absorption of water containing these metals [9]. Another study says that microbial and chemical pollutants are the main factors responsible exclusively or in combination for various public health problems due to violation of standards set by WHO of drinking water quality in Pakistan [10].

The present study is designed to have a demographic survey of the portability of drinking water in a metropolitan city, Karachi. This study was aimed to investigate the 
common sources of fecal contamination in drinking water. This study has helped us to design a few recommendations to avoid this waterborne deadly disease.

\section{Methodology}

\subsection{Inclusion Criteria}

Random selection of local water source used for human and animal consumption in the above mentioned localities, samples were un-boiled un-chlorinated

\subsection{Exclusion Criteria}

Any bottled water available in market as well chlorinated and boiled water samples were excluded.

\subsection{Informed consent}

Meeting was scheduled with every individual participant whose water source was selected and informed consent was read aloud.

Ethical consideration included informed consent form provided participants with an overview of the study objectives. The right of the participants to refuse to answer any questions, as well to end the interview at any time was briefed, before inclusion in the study. Every subject had been informed about the procedure of collecting water samples in the meeting.

\subsection{Administration of Questionnaire}

Eligible candidates were first briefed about the objectives of the study followed by face to face interview.

\subsection{Data Collection Instrument}

Questionnaire included socio economic status and personal information questions as well set of questions to predict the contributing factors towards the objectives of the study. The following principal variables were included. Use of un-boiled/un-boiled drinking water, socio economic living conditions, water source, and cleaning procedure and duration of storage tank at the time of interview.

\subsection{Debriefing and Referrals}

After the completion of interview, a debriefing session was held with participants to allow the interviews to respond to any question that the participants may have had. Information was also provided to participants during this session on the mode of transmission as well prevention and contributing factors of diarrheal infection due to use of contaminated water. All participates were referred to the lab for collection of reports after evaluation of water samples.

\subsection{Water Collection and Laboratory Processing}

Following areas were selected for the study after being constantly reported for high 
number of diarrheal cases by the residing population during another surveillance to evaluate water as contributing factor for the disease. About 50 water samples from different sources and places of Karachi and 50 samples from Bhens coloney used for humans and animals consumption were selected with in the period of five months started from May 2015 till Sep 2015. Water samples from areas of Karachi including Landhi, orangi, Layari, LaloKheet, Sohrabgoath, slum Areas of Gulshan e-Iqbal, Sheer shah, Nazam-e-Abad and Malir were collected. Sterile plastic bottle in duplicates were filled with sample, placed it in a box with ice packs and brought it to IIDRL [Immunology nd infectious diseases reference laboratory] at the university of Karachi. Within 24 hours of collection, water samples were processed by MPN technique to evaluate the load of microorganism.

Water samples from municipal tap water, storage tanks, water carry tanks, water cooler and also include public filter plants of the locality were included. These are all sources that are being used by local population for drinking purpose. Water sample that is chlorinated, boiled or branded bottle water available in the locality were excluded and not processed in this study.

\subsection{Water Culture by Multiple Tube/MPN Technique}

Coliform examination consists of the inoculation of measured volumes of water into tubes of MacConkey Broth (Purple) which are incubated at $35^{\circ} \mathrm{C}$ for 48 hours. Volumes for inoculation are one $50 \mathrm{ml}$, five $10 \mathrm{ml}$ and five $1 \mathrm{ml}$ quantities of water-50 ml and 10 $\mathrm{ml}$ amounts being added to their own volume of double-strength Mac Conkey broth, while the $1 \mathrm{ml}$ amounts are each added to $5 \mathrm{ml}$ of single-strength. Water samples from fifty different areas of Karachi city were collected in duplicate and transported in sterile water containers to the lab within 12 hours of collection. In MacConkey Broth Acid formation is indicated by yellow colorations of the broth, and gas formation is indicated by an amount of gas at least sufficient to fill the concavity at the top of the Durham tube. From the number of tubes showing the presence of acid and gas, the most probable number of [presumed] coliform bacteria present in $100 \mathrm{ml}$ of the original water may be estimated by reference to probability tables.

For the differential coliform test, each MacConkey tube showing acid and gas is then subcultured into a fresh tube of MacConkey Broth and incubated at $44^{\circ} \mathrm{C}$. Formation of gas within 48 hours is practically specific for Escherichia coli and indicative of fecal pollution of the original water sample. Organisms were processed for the identification by conventional methods using biochemical reactions. Gram staining was done from these lactose fermenting and non fermenting colonies and the isolates were found to be gram negative straight rods [1]. The strains were further identified on the basis of motility, Indole, MR , VP , Citrate, Urease, Oxidase Melanin and gas production from glucose were labeled according to specific reactions [2] [8]. E. coli samples were further processed for the detection of EHEC presence. PCR was done with following primers while extraction and amplification was done by kit according to manufacturers' guidelines [DNA extraction kit, 761001D, PCR master mix, 4390939, Invitrogen].

The optimized method utilized, a $0.025 \mu \mathrm{M}$ concentration of the st $x 2$ probe, $1.25 \mathrm{U}$ 
of AmpliTaq Gold (Applied Biosystems), and $0.5 \mu \mathrm{l}$ of sample template in a total volume of $25 \mu \mathrm{l}$. The amplification program included an initial polymerase activation step, $10 \mathrm{~min}$ at $94^{\circ} \mathrm{C}$, and 40 cycles of $20 \mathrm{~s}$ at $94^{\circ} \mathrm{C}$ and $25 \mathrm{~s}$ at $63^{\circ} \mathrm{C}$, performed on a Smart Cycler thermal cycler. Fluorescence values were recorded in each round during the $25-\mathrm{s}, 63^{\circ} \mathrm{C}$ annealing-extension step [9].

\begin{tabular}{cccc} 
Strain & Target Gene & Oligonucleotide Sequence & Amplicon Size (bp) \\
EHEC & stx 2 & GGGTACTGTGTGCCTGTTACTGG & 510 \\
& \multicolumn{3}{c}{ GCTCTGGATGCATCTCTGGT }
\end{tabular}

\section{Results}

Out of fifty processed samples $32(64 \%)$ were positive for the presence of different microorganisms. Fecal coli forms $8 / 19$ (16\%) were isolated from different sources. There were 3 (6\%) samples, which contain Klebsiella spp. and 6 (12\%) Pseudomonas spp. There were $5(10 \%)$ samples, which contain the presence of combination of different organisms in the same sample (Table 1). This shows poor sanitation and high level of contamination in water used for the local community as shown by bar graphs in Figure 1.

Similarly water samples processed from Bhens colony showed even worse situation where 37 (74\%) samples were positive for the presence of microorganisms. There were 16 (32\%) samples indicative of fecal coliforms while $4 \%$ were Klebsiella spp. Also, 4 (8\%) samples were positive for the presence of Pseudomonas spp. It is very important to note as indicated in Figure 2, that 2 (4\%) samples were positive for the presence of Salmonella spp. [non typhoid]. Similarly 8 (16\%) samples showed mix combination of different organisms (Table 2).

The positive samples were further processed for the presence of EHEC isolates and 2 samples were positive for EHEC. They were isolated from storage tank and water carry tank. This high level of contamination clearly showed how diarrheal pathogens act as major contributing factor in spread of diarrhea through water sources.

Distribution of Positive Organism from different areas of Karachi

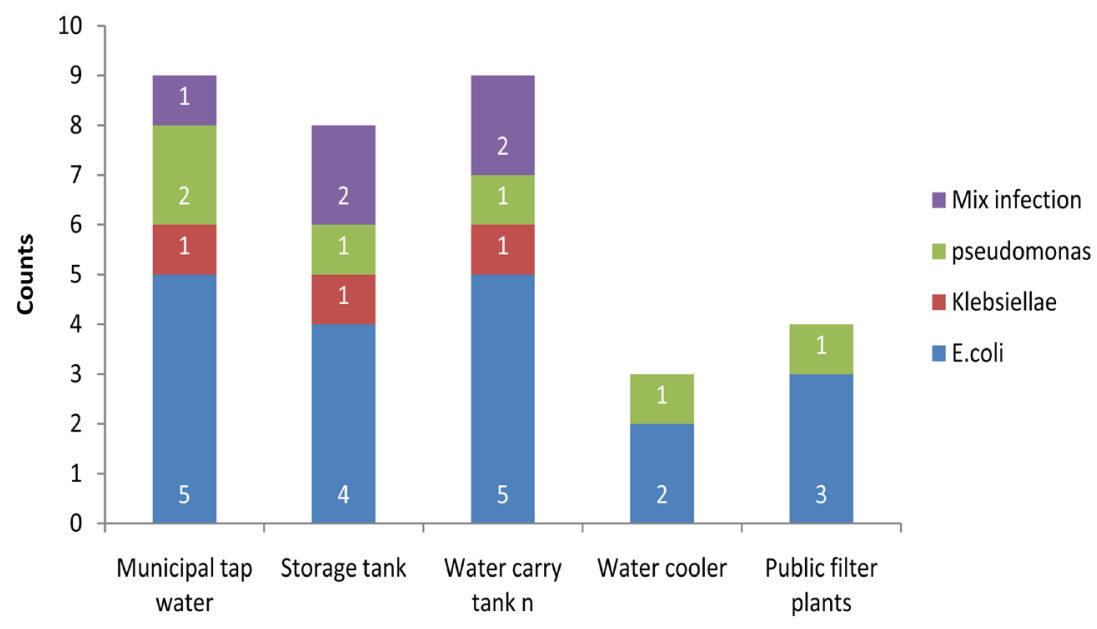

Figure 1. Distribution of positive organism from different areas of Karachi. 


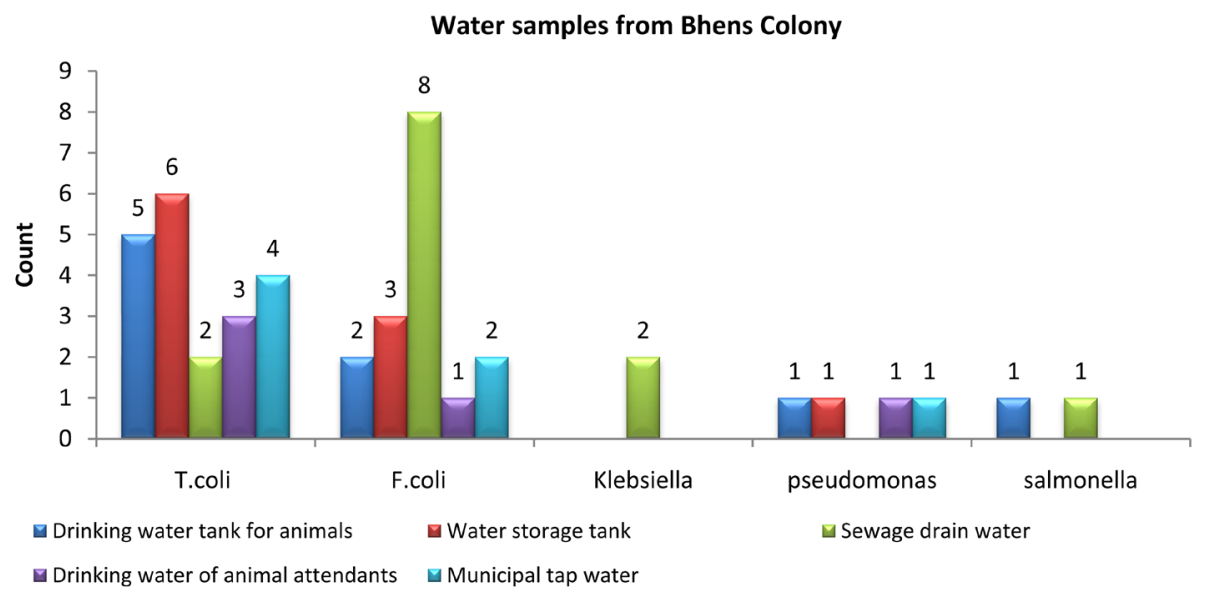

Figure 2. Water samples from Bhens Colony.

Table 1. Demographic study for the presence of enteric pathogens of water samples from different localities of Karachi.

\begin{tabular}{|c|c|c|c|c|c|c|}
\hline \multirow[t]{2}{*}{ Source of water } & $\begin{array}{l}\text { Municipal } \\
\text { tap water }\end{array}$ & Storage tank & $\begin{array}{l}\text { Water carry } \\
\text { tank }\end{array}$ & Water cooler & $\begin{array}{l}\text { Public filter } \\
\text { plants }\end{array}$ & $\begin{array}{c}\text { Total } \\
\text { samples }\end{array}$ \\
\hline & $\mathrm{N}=10$ & $\mathrm{~N}=10$ & $\mathrm{~N}=10$ & $\mathrm{~N}=10$ & $\mathrm{~N}=10$ & $\mathrm{~N}=50$ \\
\hline Positive samples & 9 & 8 & 8 & 3 & 4 & 32 \\
\hline E.coli & $\begin{array}{l}\quad 5 \\
\text { T. coli for } \mathrm{m} 3 \\
\text { F. coli for } \mathrm{m} 2\end{array}$ & \begin{tabular}{c}
\multicolumn{1}{c}{4} \\
T. coli for $\mathrm{m} 1$ \\
F. coli for $\mathrm{m} 3$
\end{tabular} & $\begin{array}{l}\quad 5 \\
\text { T. coli for m } 3 \\
\text { F. coli for m } 2\end{array}$ & $\begin{array}{c}2 \\
\text { T. coli for } \mathrm{m} 2 \\
\text { F. coli for } \mathrm{m} 0\end{array}$ & $\begin{array}{c}3 \\
\text { T. coli for } \\
\mathrm{m} 2 \\
\text { F. coli for } \mathrm{m} \\
1\end{array}$ & 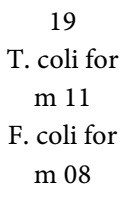 \\
\hline Klebsiellae & 1 & 1 & 1 & 0 & 0 & 3 \\
\hline pseudomonas & 2 & 1 & 1 & 1 & 1 & 6 \\
\hline Mix infection & 1 & 2 & 2 & 0 & 0 & 5 \\
\hline $\begin{array}{l}\text { Combination } \\
\text { of Organisms }\end{array}$ & $\begin{array}{c}\text { E. colit } \\
\text { Seudomonas } \\
+ \text { Salmonella }\end{array}$ & $\begin{array}{c}\text { E. coli }+ \\
\text { Pseudomonas } \\
\quad \text { and } \\
\text { E. coli }+ \text { Kleb- } \\
\quad \text { siella }\end{array}$ & $\begin{array}{c}\text { E. coli }+ \\
\text { Klebsiellae spp }+ \\
\text { Pseudomonas } \\
\text { and } \\
\text { E. coli }+ \\
\text { Salmonella }\end{array}$ & - & - & 6 \\
\hline
\end{tabular}

Table 2. Water samples from Bhens colony.

\begin{tabular}{cccccc}
\hline Source of water & $\begin{array}{c}\text { Drinking water } \\
\text { tank for animals }\end{array}$ & $\begin{array}{c}\text { Water } \\
\text { storage tank }\end{array}$ & $\begin{array}{c}\text { Sewage drain } \\
\text { water }\end{array}$ & $\begin{array}{c}\text { Drinking water of } \\
\text { animal attendants }\end{array}$ & $\begin{array}{c}\text { Municipal } \\
\text { tap water }\end{array}$ \\
\hline Total 50 & 10 & 10 & 10 & 10 & 10 \\
E.coli & 7 & 9 & 10 & 5 & 6 \\
Klebsiella & T. coli 5 & T. coli 6 & T. coli 2 & T. coli 3 & $\begin{array}{c}\text { T. coli } 4 \\
\text { Pseudomonas }\end{array}$ \\
Salmonella & 1 & F. coli 3 & F. coli 8 & F. coli 1 & F. coli 2 \\
Mix & 1 & - & 2 & - & - \\
& $\begin{array}{c}\text { E.coli }+ \\
\text { Pseudomonas }\end{array}$ & Salmo + E. coli & $\begin{array}{c}4 \text { diff } \\
\text { combination }\end{array}$ & - & E. coli + Pseudo \\
\hline
\end{tabular}




\section{Discussion}

Analysis of water samples showed that only 18 out of 50 samples were satisfactory for drinking purpose. In our results, the worse was the situation in water samples collected from Bhens colony where only 13/50 samples were satisfactory, which reflected the presence of organisms of public health importance including E. coli, Pseudomonas spp., Klebsiella spp., Salmonella spp. The presence of high levels of Total Coliforms Count (TCC), Total Fecal Coliform count (TFC) is a matter of great concern because, according to WHO guideline there should be zero tolerance of these organisms in drinking water. Municipal pipe lines running parallel to drinking water pipe lines, water stored in the household contaminated containers or water transported in contaminated tankers from far of places is more likely to be the reasons of contamination. Inadequate chlorination or dilution of it due to presence of high level of organic matter is associated along with poor hygiene and inadequate sanitation. Specific risks are identified through sanitary inspection of the water source and its surrounding. It was found that at certain points there were open sewage lines or sewage lines running parallel to drinking water lines. The presence of EHEC in Bhens colony water samples is indicative of contamination of animal feces in local water sources used for human consumption and most probably can cause diarrheal disease among residing population. This study has some limitations, like shortage of funds to limited available resources, and specified time period. Lack of funds and limited available resources, this study was conducted to a short period of time during summer season, in order to get clear and perfect view of the worse situation, while the study duration should be expended to at least one year to depict seasonal variation as well as co-relation with spread of diseases. More samples from different sources and areas should be included to avoid limitations of study. In spite of all above mentioned factors it was found that there was lack of awareness about these water borne infections and importance of boiled water for human health. Government should promote national policies and investments that support case management of diarrhea and its complications. Government also needs to make sure the access to safe drinking-water and sanitation in the country. Research should be to develop and test all possible water sources in order to elevate hospitalization burden due to diarrhea where water is involved as contributing factor in the spread of diarrhea. It is needed to build capacity in implementing preventive interventions, including sanitation, source water improvements, and household water treatment and safe storage.

\section{References}

[1] Payen, G. (2011) Worldwide Needs for Safe Drinking Water Are Underestimated: Billions of People Are Impacted. AquaFed, Paris.

[2] Pitkänen, T., Paakkari, P., Miettinen, I.T., Heinonen-Tanski, H., Paulin, L., Hänninen, M.-L. (2007) Comparison of Media for Enumeration of Coliform Bacteria and Escherichia coli in Non-Disinfected Water. Journal of Microbiological Methods, 68, 522-529. http://dx.doi.org/10.1016/j.mimet.2006.10.007 
[3] Rompré, A., Servais, P., Baudart, J., de-Roubin, M.-R., Laurent, P. (2002) Detection and Enumeration of Coliforms in Drinking Water: Current Methods and Emerging Approaches. Journal of Microbiological Methods, 49, 31-54. http://dx.doi.org/10.1016/S0167-7012(01)00351-7

[4] Bhutta, Z.A., Das, J.K., Walker, N., Rizvi, A., Campbell, H., Rudan, I., et al. (2013) Interventions to Address Deaths from Childhood Pneumonia and Diarrhoea Equitably: What Works and at What Cost? The Lancet, 381, 1417-1429. http://dx.doi.org/10.1016/S0140-6736(13)60648-0

[5] Wagner, E.G. and Lanoix, J.N. (1958) Excreta Disposal for Rural Areas and Small Communities.

[6] Azizullah, A., Khattak, M.N.K., Richter, P. and Häder, D.-P. (2011) Water Pollution in Pakistan and Its Impact on Public Health-A Review. Environment International, 37, 479497. http://dx.doi.org/10.1016/j.envint.2010.10.007

[7] Memon, G.R., Joubish, F.M. and Khurram, A.M. (2010) Impact of Parental Socio-Economic Status on Students' Educational Achievements at Secondary Schools of District Malir, Karachi. Middle-East Journal of Scientific Research, 6, 678-687.

[8] Khan, A., Farooqui, A. and Kazmi, S.U. (2011) Presence of Helicobacter pylori in Drinking Water of Karachi, Pakistan. The Journal of Infection in Developing Countries, 6, 251-255.

[9] Jinneman, K.C., Yoshitomi, K.J. and Weagant, S.D. (2003) Multiplex Real-Time PCR Method to Identify Shiga Toxin Genes stx1 and stx2 and Escherichia coli O157: H7/H-Serotype. Applied and Environmental Microbiology, 69, 6327-6333. http://dx.doi.org/10.1128/AEM.69.10.6327-6333.2003

[10] Karim, Z. (2011) Risk Assessment of Dissolved trAce Metals in Drinking Water of Karachi, Pakistan. Bulletin of Environmental Contamination and Toxicology, 86, 676-678. for you:

Accepting pre-submission inquiries through Email, Facebook, LinkedIn, Twitter, etc.

A wide selection of journals (inclusive of 9 subjects, more than 200 journals)

Providing 24-hour high-quality service

User-friendly online submission system

Fair and swift peer-review system

Efficient typesetting and proofreading procedure

Display of the result of downloads and visits, as well as the number of cited articles

Maximum dissemination of your research work

Submit your manuscript at: http://papersubmission.scirp.org/

Or contact ijcm@scirp.org 